Плодоводство и виноградарство Юга России № 56(02), 2019 г.

УДК 634.23:632.938.1

DOI 10.30679/2219-5335-2019-2-56-157-170

ПЕРСПЕКТИВНЫЕ

УСТОЙЧИВЫЕ К КОККОМИКОЗУ

СОРТА ВИШНИ

ДЛЯ ЮГА РОССИИ 1

Кузнецова Анна Павловна

канд. биол. наук

зав. лабораторией питомниководства

e-mail: anpalkuz@mail.ru

Дрыгина Анна Игоревна

мЛ. научный сотрудник

лаборатории питомниководства

Федеральное государственное

бюджетное научное учреждение

«Северо-Кавказский федеральный

научный иентр садоводства,

виноградарства, виноделия»,

Краснодар, Россия

Маджар Дмитрий Андреевич

канд. с.-х. наук

глава КФХ «Маджар Д.А.»,

Краснодарский край, Россия

Гриднев Сергей Иванович

агроном питомника

ООО «ОПХ им. К.А. Тимирязева»,

Краснодарский край, Россия

Ленивцева Мария Сергеевна

канд. с.-х. наук,

Санкт-Петербург, Россия

Создание устойчивых сортов к коккомикозу (одному из самых вредоносных заболеваний вишни и черешни) соответствует стратегическим направлениям развития Краснодарского края № 1: кардинальное повышение качества и продолжительности жизни населения. В этой связи важную роль
UDC 634.23:632.938.1

DOI 10.30679/2219-5335-2019-2-56-157-170

\section{PROMISING RESISTANT TO COCCOMYCOSIS CHERRY VARIETIES FOR THE SOUTH OF RUSSIA}

Kuznetsova Anna Pavlovna

Cand. Biol. Sci.

Head of Laboratory of Nursery planting

e-mail: anpalkuz@mail.ru

Drygina Anna Igorevna

Junior Research Associate

of Laboratory of Nursery planting

Federal State Budget

Scientific Institution

"North Caucasian Federal

Scientific Center of Horticulture,

Viticulture, Wine-making»,

Krasnodar, Russia

Madzhar Dmitriy Andreyevich

Cand. Agr. Sci

Head of the Farm «Madzhar D.A.»,

Krasnodar Region, Russia

Gridnev Sergey Ivanovich

Agronomist of Nursery

LTD «EPF named after K.A. Tiviryazeva», Krasnodar Region, Russia

Lenivtseva Maria Sergeyevna

Cand. Agr. Sci,

Sankt-Peterburg, Russia

The creation of resistant varieties to coccomycosis (one of the most harmful diseases of cherry and sweet cherry) corresponds to the strategic directions for the development of Krasnodar Territory No. 1: a cardinal improvement in the quality and longevity of the population. In this regard,

\footnotetext{
${ }^{1}$ Поддержано грантом №16-44-230323 p_a Российского фонда фундаментальных исследований и администрации Краснодарского края, в рамках госзадания Минобрнауки России.
} 
играет обеспечение населения качественной экологически чистой продукцией. Создание устойчивых сортов позволит избежать или сократить количество опрыскиваний химическими средствами защиты, уменьшит издержки при производстве плодов и, главное, поможет в решении задачи получения экологически безопасной продукции. В результате многолетней работы по созданию устойчивых к коккомикозу генотипов, выделены в элиту формы 3-33-34 и Южанка, которые по ряду хозяйственно ценных и адаптивно значимых признаков заметно отличаются от стандартных сортов. Так, в условиях Горячеключевского района, где в результате многолетнего мониторинга отмечено наличие в популяции наиболее вирулентных клонов, преодолевающих устойчивость гена «А», полный урожай получен только у элит Южанка и 3-33-34 на подвоях селекции СКФНЦСВВ - до 16 т/га. Они отличались по наименьшим показателям: среднего количества пустул коккомикоза на $1 \mathrm{~cm}^{2}$ листа $(0,08 \pm 1,1$ до $5,25 \pm 1,3)$, индекса устойчивости (0-1357), генеративной активности гриба (0-2629). Также выделена в элиту вишня Тимирязевская, с поздним развитием коккомикоза. Её отличительные черты оригинальный вкус плодов, высокая урожайность (до 100 кг с дерева). Выделенные элитные формы также проявили комплексную устойчивость к засухе, высоким летним температурам и ряду заболеваний, что является свидетельством их пригодности для ресурсо - энергосберегающих технологий возделывания садовых насаждений.

Ключевые слова: КОККОМИКОЗ, ЭЛИТНЫЕ ФОРМЫ ВИШНИ, ЭПИФИТОТИИ, УСТОЙЧИВОСТЬ, ФОРМЫ С ПОЛИГЕННЫМ ТИПОМ УСТОЙЧИВОСТИ, ВИРУЛЕНТНЫЕ БИОТИПЫ, УРОЖАЙНОСТЬ, АДАПТИВНОСТЬ an important role is played by providing the population with the high-quality environmentally friendly products. The creation of resistant varieties Will allow you to avoid or reduce the number of chemical sprayings, to reduce the fruit production costs, and the most importantly, to help in solving the problem of obtaining environmentally safe products.

As a result of many years work on the creation of genotypes resistant to coccomycosis, the forms of 3-33-34 and Yuzhanka were selected to the elite, which, due to a number of economically valuable and adaptively significant traits, differ markedly from standard varieties. So, under the conditions of the Goryachy Klyuch district, where as a result of long-term monitoring, it is noted in the population the most virulent clones overcoming the resistance of the A gene, the full yield was obtained only from the elites of Yuzhanka and 3-33-34 on the rootstocks of the NCFSCHVW breeding - to $16 \mathrm{t} / \mathrm{ha}$. They are differed on the lowest indicators: the average number of coccomycosis pustules per $1 \mathrm{~cm}^{2}$ of leaf $(0.08 \pm 1.1$ to $5.25 \pm 1.3)$, resistance index (0-1357), generative activity of the fungis (0-2629). Timiryazevskaya cherry are also selected to the elite, with the late development of coccomycosis. Its distinctive features - the original taste of the fruits, high yield, up to $100 \mathrm{~kg}$ per tree. These elite forms also showed the complex resistance to drought, high summer temperatures and a number of diseases, which proved their suitability for resource-saving technologies of gardening.

Key words: COCCOMYCES, CHERRY ELITE FORMS, EPIPHYTOTICS, RESISTANCE, FORMS WITH POLYGENIC TYPE OF RESISTANCE, VIRULENT BIOTYPES, YIELD CAPACITY, ADAPTABILITY 
Введение. При изучении косточковых культур одним из наиболее важных показателей для выделения форм является устойчивость к стрессфакторам абиотического и биотического характера. По отношению к формам черешни и вишни и производным от них наиболее вредоносным заболеванием является коккомикоз (возбудитель - Coccomyces hiemalis Higgins, Blumeriella jaapii (Rehm) Arx). Анализ литературных данных показывает, что изучения устойчивости генетических ресурсов к $C$. hiemalis у нас и за рубежом начаты давно (в России с 1960 гг.) [1-12].

В результате отбора и направленной селекции на устойчивость к болезни как в России, так и за рубежом в последние годы созданы генотипы резистентные к коккомикозу. В России это гибриды вишни ВП-1, Рубин, Возрождение № 1, Олимп, Пушкинская, Акварель, Фея, Практичная, Зеленоглазка; сорта вишни Ливенская, Мценская, Новелла; черешня Поэзия; клоновые подвои В-2-180, В-2-230, Русинка, Бусинка, Юбилейная 3, Память Сахарова; образцы вишни Hindenburg, Обновленная, Ночка 2, Ранняя 2, черешни - Мускатная Красная, Ройяль 23/16, Сладкая Сентябрьская, Цешенская, Октябрьская, а также сорта Алмаз, Гизела 6 [13-20]. Однако сортимент не отвечает запросам питомниководства, садоводства и селекции, особенно в условиях юга России, в силу как хозяйственно ценных признаков сортов, природно-климатических условий, так и состава популяции коккомикоза [21-23].

Ранее было установлено, что по сравнению с популяциями из других регионов наиболее вирулентна популяция из Краснодарского края, так как в ней наибольший процент вирулентных 3 и 4 рас. Четвертая раса поражает донор устойчивости к коккомикозу Алмаз, содержащий ген А, переданный от Падоцеруса-М, полученного с участием вишни Маака. В условиях Краснодарского края результаты исследований показали, что у форм быстро преодолевается моногенная устойчивость к коккомикозу [24-27], поэтому большой интерес представляют формы с полигенным типом устойчивости. 
Плодоводство и виноградарство Юга России № 56(02), 2019 г.

В результате многолетних исследований с помощью отдаленной гибридизации с привлечением доноров и источников с различными типами устойчивости к коккомикозу (с вертикальной, горизонтальной устойчивостью, с поздним развитием инфекции) в ФГБНУ СКЗНЦСВВ получено более 500 генотипов вишни.

Целью нашей работы было выделение из коллекции устойчивых к коккомикозу генотипов мелкокосточковых культур - элитных форм вишни, пригодных для ресурсо-энергосберегающих технологий ведения садоводства.

Объекты и методы исследований. Оценку устойчивости к коккомикозу в полевых и искусственных условиях проводили по методике М.С. Ленивцевой [28], хозяйственно-ценных характеристик вишни - с помощью стандартных методик [29-30]. Исследования проводились в Краснодаском крае: в насаждениях ООО «ОПХ им. К.А. Тимирязева» (Усть-Лабинский рн), ЗАО «ОПХ Центральное» СКФНЦСВВ (г. Краснодар), ЛПХ «Маджар Д.А.» (Горячеключевской р-н), ООО «Садко» (Темрюкский р-н).

обсуждение результатов. С 1989 года в СКФНЦСВВ проводятся исследования по изучению системы «коккомикоз - хозяин - среда». Изучаются доноры и источники устойчивости к патогену в условиях юга России. Выявлено доминирование устойчивости у вишни Маака, Prunus serrulata, P. Maximowiczii (вишни Максимовича). И хотя устойчивость экспрессируется у этих доноров во втором и третьем поколениях гибридов, имеется немало фактов, доказывающих, что в популяциях достаточно высока встречаемость клонов гриба, способных сильно поражать производные от них сорта (на примере наиболее популярного в нашей стране донора Алмаз). Поэтому необходимо использовать не только производные Маака, но и другие устойчивые к коккомикозу виды косточковых культур: P. kurilensis Miyabe, P. sargentii Rehd., P. incisa Thunb., P. pseudocerasus, P. subhirtella Mig., P. canescens 
Bois., P. concinna Koehne, P. conradinae (Koehne) Yu. Et Li., P. padus L., P. serotina Ehrh., P. asiatica Kom., P. incana Stev., P. glandulosa Thunb [20].

В коллекции ФНЦСВВ имеются гибриды - производные от этих видов, полученные в результате отдаленной гибридизации. Весь полученный селекционный материал оценивается по устойчивости к стресс-факторам, наиболее часто проявляющимся в условиях юга России, также проводится изучение их хозяйственно ценных качеств для использования в садоводстве в виде привоев и подвоев.

По многолетним данным, среди отдаленных гибридов, полученных от вишни, отмечены формы с хозяйственно ценными признаками: 3-33-34, Южанка, Тимирязевская, которые выделены в элиту.

Вишни Южанка и 3-33-34 в полевых условиях практически не поражались коккомикозом. В насаждениях ст. Бакинской Горячеключевского района, где отмечалось наличие наиболее вирулентных клонов на фоне отсутствия химической защиты, урожай был получен только на них, хотя испытывалось более 30 новых сортов вишни и черешни. Для определения типа устойчивости проведен детальный анализ этих образцов (табл. 1).

Необходимо отметить, что выбранный как контрольный сорт черешни Бигарро Оратовского с полигенным типом устойчивости, который с 1987 по 2019 год в других хозяйствах проявлял устойчивость к коккомикозу, в хозяйстве ст. Бакинской поражался на 4 балла. В этом хозяйстве участок расположен в пойме реки Псекупс, где отмечается высокая влажность воздуха в весенний период, и каждый год наблюдается эпифитотийное развитие инфекции с ранним проявлением болезни уже в середине мая.

При мониторинге состава популяций в Краснодарском крае полученные данные за последние годы свидетельствуют, что популяция из Горячего Ключа наиболее вирулентна, исходя из соотношений частот фенотипов вирулентности 30 и 01 в 2016 году и по встречаемости только фенотипа вирулентности 70 (который преодолевает устойчивость сорта Алмаз) в 2017 и 2018 гг. 
Таблица 1 - Выделение высоко устойчивых к коккомикозу генотипов рода Prunus L., СКФНЦСВВ в условиях Горячеключевского р-на (ст. Бакинская)

\begin{tabular}{|c|c|c|c|c|c|c|c|c|}
\hline \multirow{2}{*}{$\begin{array}{c}\text { Название } \\
\text { образца }\end{array}$} & $\begin{array}{c}\text { Мах. балл. } \\
\text { пораже- } \\
\text { ния } \\
\text { листа }\end{array}$ & \multicolumn{2}{|c|}{$\begin{array}{c}\text { Среднее } \\
\text { количество } \\
\text { пустул }\end{array}$} & \multicolumn{2}{|c|}{$\begin{array}{c}\text { Индекс } \\
\text { устойчивости }\end{array}$} & \multicolumn{2}{|c|}{$\begin{array}{c}\text { Генеративная } \\
\text { активность } \\
\text { гриба }\end{array}$} \\
\cline { 3 - 9 } & 2017 & 2018 & 2017 & 2018 & 2017 & 2018 \\
\hline \multicolumn{7}{|c|}{ Сорта и формы черешни и вишни } \\
\hline $3-33-34$ & 0,5 & $1,7 \pm 1,6$ & $0,16 \pm 1,4$ & 4619 & 0 & 2717 & 0 \\
\hline Южанка & 0,5 & $5,2 \pm 1,3$ & $0,08 \pm 1,1$ & 13671 & 0 & 2629 & 0 \\
\hline $\begin{array}{c}\text { Бигарро } \\
\text { Оратов- } \\
\begin{array}{c}\text { ского } \\
\text { (контроль) }\end{array}\end{array}$ & 4 & $14 \pm 1,6$ & 0,05 & 99988 & 4250 & 7142 & 8500 \\
\hline $\begin{array}{c}\text { Француз- } \\
\text { ская } \\
\text { черная } \\
\text { (контроль) }\end{array}$ & 4 & $10 \pm 1,3$ & $6,9 \pm 1,6$ & 750000 & 28262 & 75000 & 4096 \\
\hline
\end{tabular}

Вишня Южанка (вишня Молодежная $\times$ А $9($ Норд Стар $\times$ C. judii)) Дерево среднерослое. Срок цветения средне-ранний. По срокам созревания относится к ранним. Плоды больше крупного размера (средняя масса 4,8 г), округлые, цвет темно-бордовый, почти черный (рис. 1). Как было показано выше в условиях Краснодарского края Южанка проявляет высокую устойчивость к коккомикозу в различных эколого-географических зонах даже при наличии в популяциях вирулентных клонов и эпифитотийного развития инфекции. Продуктивность высокая. В насаждениях 2012 г. посадки в условиях Горячеключевского р-на при схеме $3 \times 2$ на низкорослых подвоях 11-15, 11-4, 3-21 селекции ФГБНУ СКФНЦСВВ получено в среднем 10 кг плодов вишни с дерева (16 т/га), в Темрюкском р-не при схеме посадки 3x4 20 кг с дерева (16 т/га). 
Плодоводство и виноградарство Юга России № 56(02), 2019 г.

Достоинства сорта: зимостойкий, высокоурожайный, высокая устойчивость к абиотическим стрессорам, патогенам, засухе, а также к переувлажненным почвам.
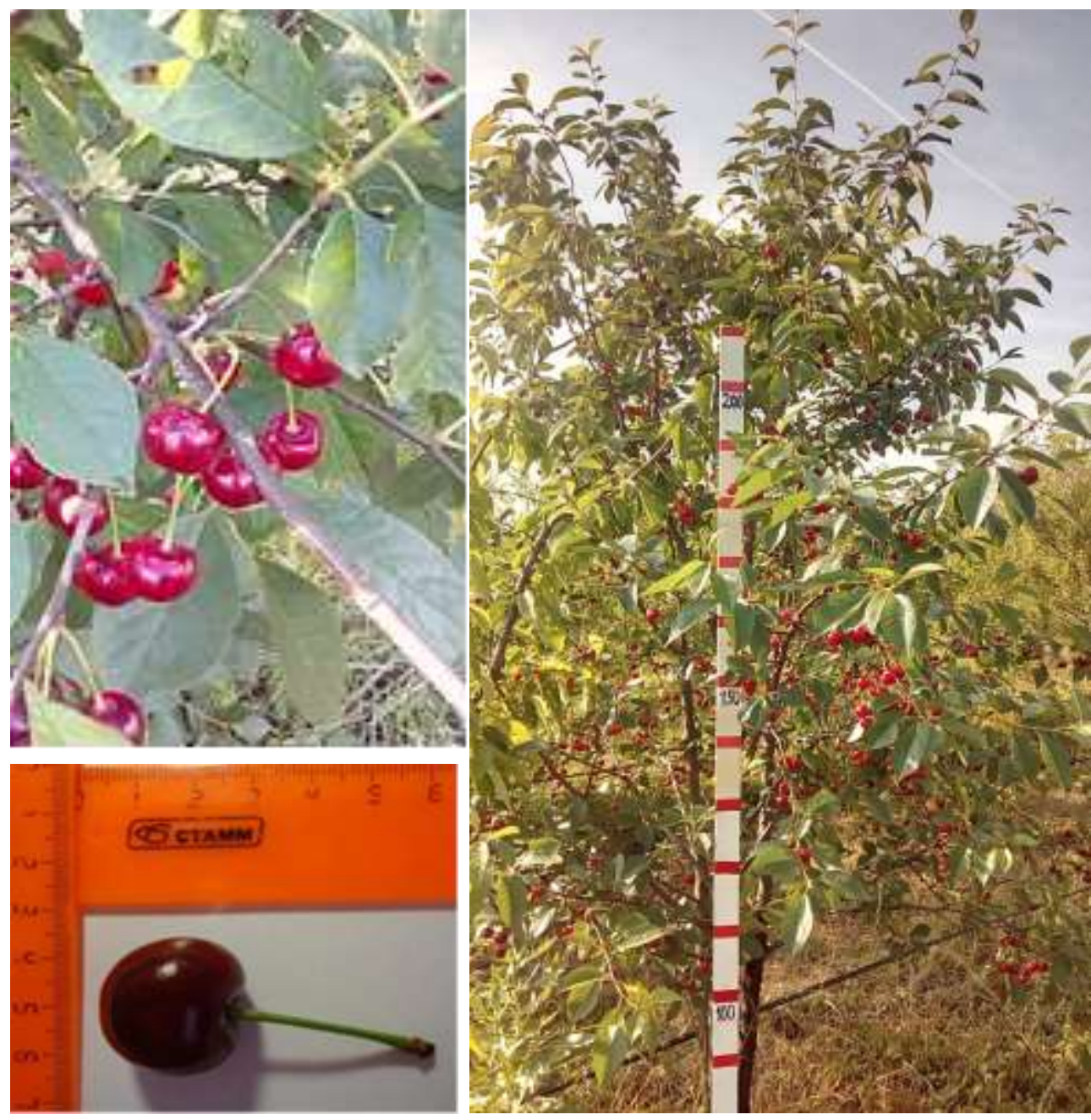

Рис. 1. Урожайность сорта Южанка на подвое 3-21 в условиях Горячеключевского района на тяжелосуглинистых почвах

Элитная форма вишни 3-33-34 (Молодежная х (смесь пыльцы Норд Стар и C.lannesiana №2)). Дерево среднерослое. Форма кроны раскидистая. Относится по срокам созревания к очень ранним. Масса плода 6 г., отличается сухим отрывом, пригодна для механизированного сбора урожая. Образец с полигенным типом устойчивости к коккомикозу. В условиях Горячеключевского р-на при схеме 3х2 на среднерослом подвое С3 9м селекции 
СКФНЦСВВ отмечена урожайность 10 кг с дерева (16 т/га) за счёт высокой устойчивости к коккомикозу. При эпифитотийном развитии инфекции и наличии самых вирулентных клонов выделяется по наименьшему значению количества пустул от $0,16 \pm 1,4$ до $1,7 \pm 1,6$ на $1 \mathrm{~cm}^{2}$ листа и индекса устойчивости (0 - 4619) (рис. 2).

Достоинства: зимостойкий, высокая адаптивность к абиотическим условиям среды, устойчивость к патогенам, засухе, переувлажненым почвам, высокоурожайный, пригоден для механизированного сбора урожая.

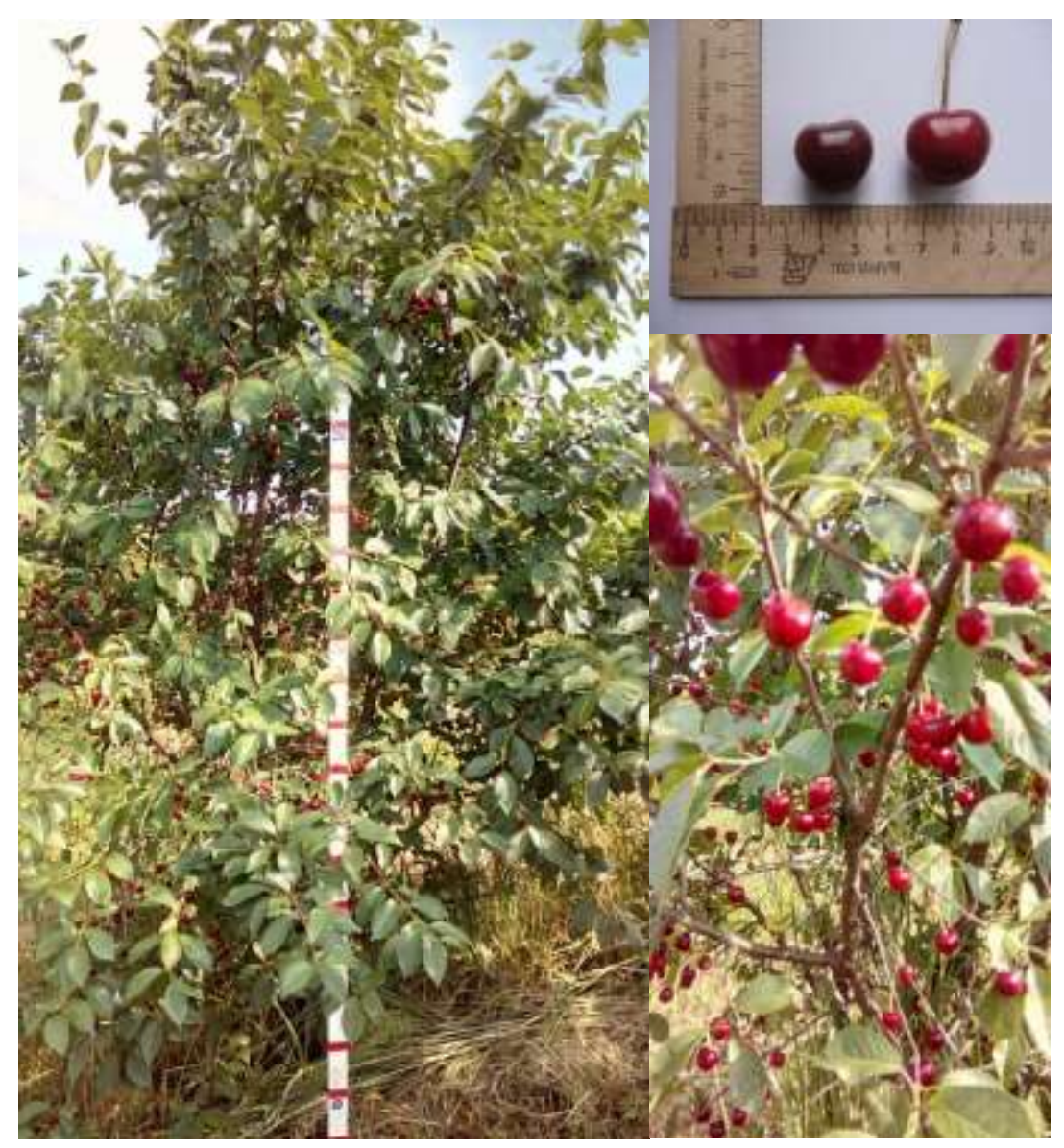

Рис. 2. Урожайность формы 3-33-34 в условиях Горячеключевского района на тяжелосуглинистых почвах (подвой С3 9м)

По высокой урожайности, оригинальным вкусовым качествам плодов и высокой адаптивности к абиотическим и биотическим стрессорам выде- 
лена в элиту форма вишни Тимирязевская (рис. 3). При изучении её устойчивости к коккомикозу в Усть-Лабинском р-не, где так же в популяции имеются вирулентные клоны, преодолевающие устойчивость гена А, у неё отмечено позднее развитие инфекции.

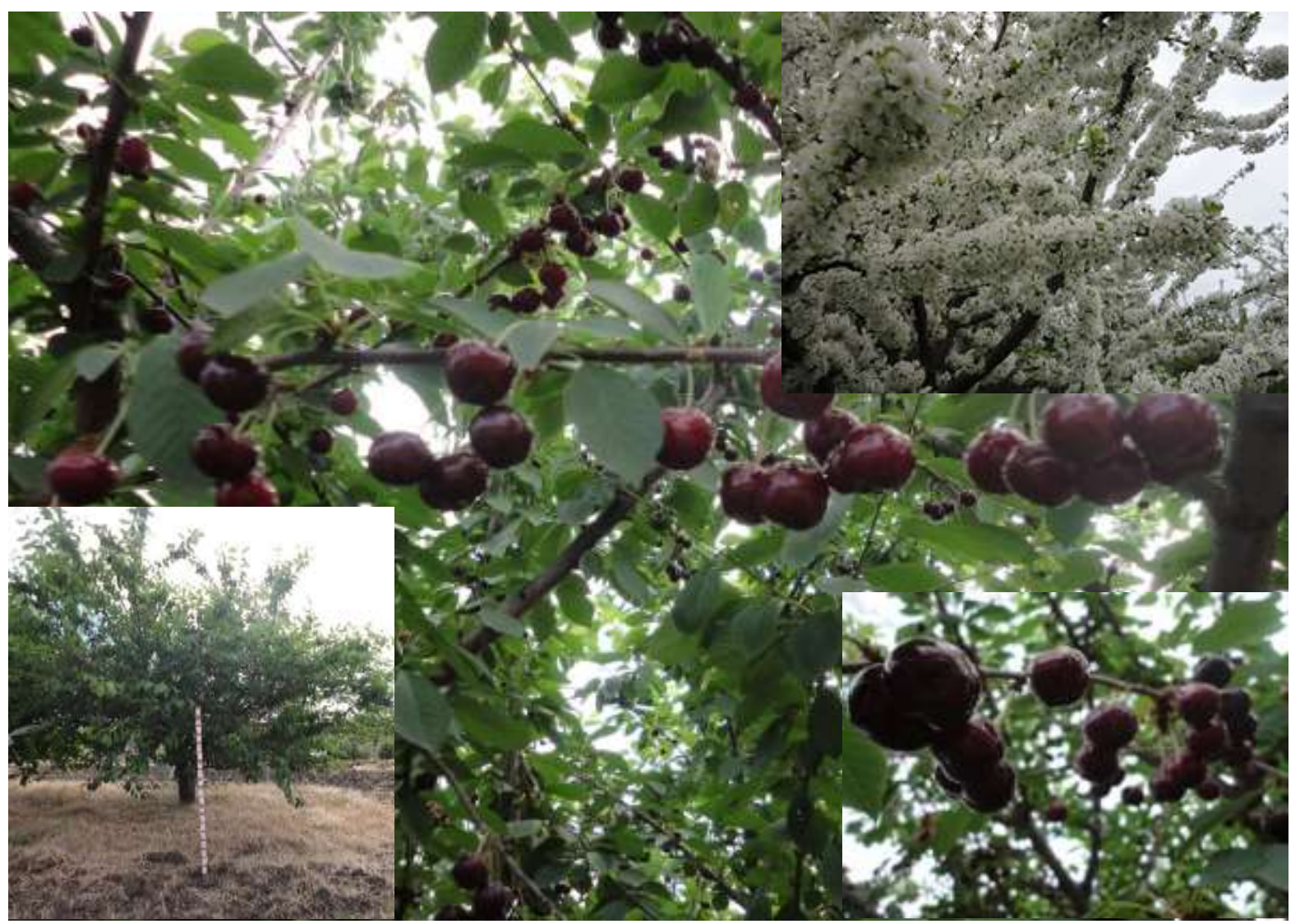

Рис. 3. Высота, цветение и урожайность деревьев вишни сорта Тимирязевская/антипка, 2018 г.

Вишня Тимирязевская выделена в ООО ОПХ им. К.А. Тимирязева из гибридов Л.И. Тараненко семьи (II-5-14-48). Дерево среднерослое. Срок цветения средне-ранний. Срок созревания средний. Ягоды больше среднего размера (масса 5 г), округлые, темно-красного цвета, могут быть употреблены в незрелом виде. Особенностью плодов является изменение цвета мякоти по мере перезревания плодов. Сорт раннего срока созревания. 
Плодоводство и виноградарство Юга России № 56(02), 2019 г.

Достоинства: оригинальный вкус, высокая зимостойкость. Сорт относится к формам с поздним развитием коккомикоза (ПРИ), высоко адаптивный сорт. Опылителями являются сорта Келлерис, Владимирская. Отличается хорошей урожайностью - до 100 кг с дерева на подвоях сеянцы черешни, схема посадки $5 \times 8$ (табл. 2). Недостаток - привитое на сеянцах черешни, антипки растение имеет большой габитус кроны.

Таблица 2 - Урожайности вишни сорта Тимирязевская (год посадки - 2000 г.), схема посадки 5х8, ООО «ОПХ им. К.А. Тимирязева» (подвой антипка)

\begin{tabular}{|l|c|c|c|}
\hline \multicolumn{1}{|c|}{ Сорт } & $\begin{array}{c}\text { Урожайность, } \\
2016 \text { г. }\end{array}$ & $\begin{array}{c}\text { Урожайность, } \\
2017 \text { г. }\end{array}$ & $\begin{array}{c}\text { Урожайность, } \\
2018 \text { г. }\end{array}$ \\
\hline Тимирязевская & 100 & 80 & 90 \\
\hline $\begin{array}{l}\text { Краснодарская } \\
\text { сладкая (контроль) }\end{array}$ & 50 & 35 & 40 \\
\hline Кирина & 25 & 20 & 20 \\
\hline
\end{tabular}

Химические показатели плодов выделенных элит вишни свидетельствуют об их высоких вкусовых качествах (табл. 3).

Таблица 3 - Химический анализ плодов вишни селекции СКФНЦСВВ

\begin{tabular}{|c|c|c|c|c|c|c|c|}
\hline ồ & 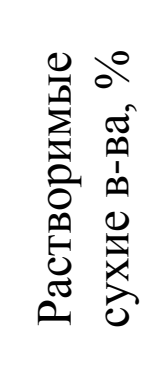 & 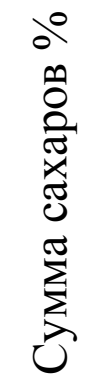 & 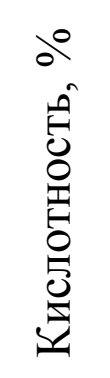 & 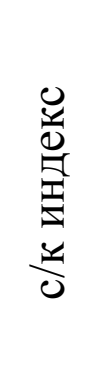 & 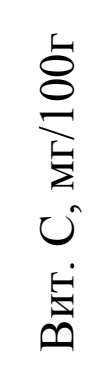 & 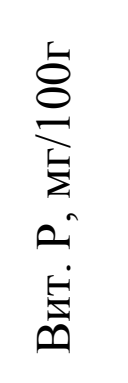 & 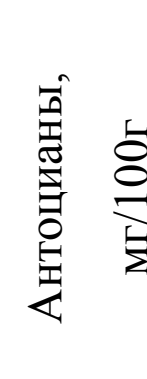 \\
\hline $3-33-34$ & 15,3 & 7,3 & 2,14 & 3,4 & 8,8 & 129,0 & 263,5 \\
\hline Вишня Тимирязевская & 17,7 & 8,4 & 1,54 & 5,4 & 9,7 & 78,8 & 340,5 \\
\hline Южанка & 19,6 & 8,6 & 1,26 & 6,8 & 8,8 & 109,8 & 148,5 \\
\hline
\end{tabular}


Плодоводство и виноградарство Юга России № 56(02), 2019 г.

Bыводы. В результате селекции на устойчивость к коккомикозу выделены в элиту формы вишни 3-33-34, Южанка, Тимирязевская, превосходящие стандартные сорта по комплексу хозяйственно ценных признаков.

На фоне эпифитотий коккомикоза и наличия в популяции наиболее вирулентных клонов в условиях Горячеключевского района дали высокий урожай только две формы вишни: 3-33-34, Южанка с горизонтальным типом устойчивости. Использование данных форм в садоводстве позволяет минимизировать применение фунгицидов химических классов и получать экологически чистую продукцию.

\section{Литература}

1. Чеботарева М.С. Состав генофонда родов Cerasus Mill., Padus Mill., Microcerasus Webb emend. Spach на устойчивости к коккомикозу в связи с задачами селекции: автореф. дис. ... канд. с.-х. наук : 06.01.05 / Чеботарева Мария Сергеевна. Ленинград, 1986. 16 с.

2. Бондаренко А.И. Устойчивость черешни и вишни к коккомикозу. Защита урожая. Кишинев, 1976. С. 20-30.

3. Вышинская М.И. исходный материал для селекции вишни и черешни на устойчивость к коккомикозу: автореф. дис. ... канд. с.-х. наук : 06.01.11 / Вышинская Мария Ивановна. Самохваловичи, 1984. 18 с.

4. Минкявичюс А.И. Монилиоз и коккомикоз вишни в Литовской ССР // Состояние и перспективы развития плодоводства в прибалтийских республиках и Ленинградской области. Вильнюс, 1966. С. 138-145.

5. Бедоидзе 3.Ш. Результаты изучения коккомикоза косточковых Восточной Грузии: автореф. дис. ... канд. биол. наук : 06.01.11 / Бедоидзе Заира Шавловна. Тбилиси, 1976. $34 \mathrm{c}$.

6. Burth U., Ramson A. Hauptfruchtform der Sprühfleckenkrankheit der Kirsche auch in der DDR. Dt. Pflanzenschutzdienst. 1970. № 24. P. 132.

7. Wolfram B. Sour cherry breeding at Dresden-Pillnitz. Acta Hortic. 2000. V. 538. P. 359-362.

8. Burkowicz A. Blumeriella jaapii (Rehm) v. Arx on cultivated stone fruits in Poland. Phytopathologische Zeitschrift. 1964. V. 51. P. 419-424.

9. Hodun G., Grzyb Z.S. Field evaluation of susceptibility to Blumeriella jaapii of selected sour cherry cultivars. Acta Hortic. 2000. V. 538. P. 151-154.

10. Budan S., Mutafa I., Stoian I., Popescu I. Field evaluation of cultivar susceptibility to leaf spot at Romania's sour cherry genebank. Acta Hortic. 2005. V. 667. P. 153-158.

11. Sjulin T.M., Jones A.L., Andersen R.L. Expression of partial resistance to cherry leaf spot in cultivars of sweet sour, duke, and European ground cherry. Plant Dis. 1989. V. 73(1). P. 56-61.

12. Schuster M. Investigation of resistance to leaf spot disease in cherries. Journal of Fruit and Ornamental Plant Research. 2004. V. 12. P. 275-279. 
13. Колесникова А.Ф., Дмитров Т.А. Результаты сортоизучения вишни в условиях средней полосы РСФСР // Селекцияя, сортоизучение, агротехника плодовых и ягодных культур. 1980. №10 (2). С. 19-29.

14. Чмир Р.А. Хозяйственно-биологическая оценка вишни и черешни в средней полосе России: автореф. дис. ... канд. с.-Х. наук : 06.01.08 / Чмир Роман Александрович. Мичуринск, 2003. 23 с.

15. Гуляева А.А., Джигадло Е.Н., Джигадло М.И. Клоновые подвои для вишни и черешни селекции ГНУ ВНИИСПК // Селекция и сорторазведение садовых культур: материалы конференции. Орел, 2007. С. 74-80.

16. Карташова О.Н. Зимостойкость и продуктивность новых сортов вишни в условиях Нечерноземья: автореф. дис. ... канд. с.-х. наук : 06.01 .05 / Карташова Ольга Николаевна. Москва, 2009. 26 с.

17. Ленивцева М.С., Орехова В.П., Лукичева Л.А. Устойчивость сортов черешни и вишни к коккомикозу (Coccomyces hiemalis Higg.) // Каталог мировой коллекции ВИР. 2010. №799. 18 c.

18. Wharton P.S., Iezzoni A., Jones A.L. Screening cherry germ plasm for resistance to leaf spot // Plant Disease. 2003. V. 87(5). P. 471-477.

19. Wharton P.S., Iezzoni A. Development of a protocol for screening cherry germplasm for resistance to cherry leaf spot // Acta Horticulturae. 2005. V. 667. P. 509-514.

20. Ленивцева М.С., Радченко Е.Е., Кузнецова А.П. Генетическое разнообразие сортов косточковых культур (род Prunus L.), устойчивых к коккомикозу // Сельскохозяйственная биология. 2017. Т. 52. № 5. С. 895-904.

21. Кузнецова А.П. Специализация и внутривидовая дифференциация возбудителя коккомикоза // Оптимизация фитосанитарного состояния садов в условиях погодных стрессов. Краснодар, 2005. С. 82-88.

22. Ленивцева М.С., Кузнецова А.П., Радченко Е.Е. Внутривидовая изменчивость Coccomyces hiemalis по признаку вирулентности к образцам черешни и вишни // Микология и фитопатология. 2016. Т. 50. № 1. С. 62-65.

23. Ленивцева М.С., Кузнецова А.П. Расовый состав популяций возбудителя коккомикоза Blumeriella jaapii(rehm) v. Arx // Труды по прикладной ботанике, генетике и селекции. 2011. Т. 168. С. 162-164.

24. Ленивцева М.С., Кузнецова А.П. Фенотипическое разнообразие трех агроклиматических зон Краснодарской популяции Coccomyces hiemalis по вирулентности к образцам черешни и вишни // Наука Кубани. 2018. №3. С.44-47.

25. Ульяновская Е.В., Артюх С.Н., Ефимова И.Л., Можар Н.В. [и др.] Сохранить и всесторонне изучить генетические ресурсы плодовых и их подвоев, ягодных, орехоплодных, цветочно-декоративных культур и винограда с целью выделения и создания доноров и источников хозяйственно значимых признаков новых сортов для обеспечения эффективности и экологизации селекции, садоводства и виноградарства: отчет о НИР (Северо-Кавказский зональный научно-исследовательский институт садоводства и виноградарства РАСХН) 2013. 786 с. № ГР: 01201265696.

26. Кружков А.В. Подбор родительских форм в селекции вишни на устойчивость к коккомикозу // Вавиловские чтения: материалы междунар. науч-практ. конф. Саратов, 2011. C. 40-41.

27. Ленивцева М.С., Кузнецова А.П. Типы и источники устойчивости косточковых культур к коккомикозу // Вестник АПК Ставрополья. 2016. № 4 (24). С. 179-182.

28. Ленивцева М.С. Изучение устойчивости косточковых культур к коккомикозу: методические указания. СПб.: ВИР, 2010. 28 с. 
29. Методика опытного дела и методические рекомендации Северо-Кавказского зонального НИИ садоводства и виноградарства. Краснодар, 2002. 215 с.

30. Программа селекционных работ по плодовым, ягодным, орехоплодным и цветочно-декоративным культурам союза селекционеров Северного Кавказа на период до 2010 г. Краснодар, 2005. 343 с.

\section{References}

1. Chebotareva M.S. Sostav genofonda rodov Cerasus Mill., Padus Mill., Microcerasus Webb emend. Spach na ustojchivosti k kokkomikozu v svyazi s zadachami selekcii: avtoref. dis. ... kand. c.-h. nauk : 06.01.05 / Chebotareva Mariya Sergeevna. Leningrad, 1986. 16 s.

2. Bondarenko A.I. Ustojchivost' chereshni i vishni k kokkomikozu. Zashchita urozhaya. Kishinev, 1976. S. 20-30.

3. Vyshinskaya M.I. iskhodnyj material dlya selekcii vishni i chereshni na ustojchivost' k kokkomikozu: avtoref. dis. ... kand. c.-h. nauk : 06.01.11 / Vyshinskaya Mariya Ivanovna. Samohvalovichi, 1984. $18 \mathrm{~s}$.

4. Minkyavichyus A.I. Monilioz i kokkomikoz vishni v Litovskoj SSR // Sostoyanie i perspektivy razvitiya plodovodstva $\mathrm{v}$ pribaltijskih respublikah i Leningradskoj oblasti. Vil'nyus, 1966. S. 138-145.

5. Bedoidze Z.Sh. Rezul'taty izucheniya kokkomikoza kostochkovyh Vostochnoj Gruzii: avtoref. dis. ... kand. biol. nauk : 06.01.11 / Bedoidze Zaira Shavlovna. Tbilisi, 1976. $34 \mathrm{~s}$.

6. Burth U., Ramson A. Hauptfruchtform der Sprühfleckenkrankheit der Kirsche auch in der DDR. Dt. Pflanzenschutzdienst. 1970. № 24. P. 132.

7. Wolfram B. Sour cherry breeding at Dresden-Pillnitz. Acta Hortic. 2000. V. 538. P. 359-362.

8. Burkowicz A. Blumeriella jaapii (Rehm) v. Arx on cultivated stone fruits in Poland. Phytopathologische Zeitschrift. 1964. V. 51. P. 419-424.

9. Hodun G., Grzyb Z.S. Field evaluation of susceptibility to Blumeriella jaapii of selected sour cherry cultivars. Acta Hortic. 2000. V. 538. P. 151-154.

10. Budan S., Mutafa I., Stoian I., Popescu I. Field evaluation of cultivar susceptibility to leaf spot at Romania's sour cherry genebank. Acta Hor-tic. 2005. V. 667. P. 153-158.

11. Sjulin T.M., Jones A.L., Andersen R.L. Expression of partial resistance to cherry leaf spot in cultivars of sweet sour, duke, and European ground cherry. Plant Dis. 1989. V. 73(1). P. 56-61.

12. Schuster M. Investigation of resistance to leaf spot disease in cherries. Journal of Fruit and Ornamental Plant Research. 2004. V. 12. P. 275-279.

13. Kolesnikova A.F., Dmitrov T.A. Rezul'taty sortoizucheniya vishni v usloviyah srednej polosy RSFSR // Selekciyaya, sortoizuchenie, agrotekhnika plodovyh i yagodnyh kul'tur. 1980. №10 (2). S. 19-29.

14. Chmir R.A. Hozyajstvenno-biologicheskaya ocenka vishni i chereshni v srednej polose Rossii: avtoref. dis. ... kand. c.-h. nauk : 06.01.08 / Chmir Roman Aleksandrovich. Michurinsk, 2003. $23 \mathrm{~s}$.

15. Gulyaeva A.A., Dzhigadlo E.N., Dzhigadlo M.I. Klonovye podvoi dlya vishni i chereshni selekcii GNU VNIISPK // Selekciya i sortorazvedenie sadovyh kul'tur: materialy konferencii. Orel, 2007. S. 74-80.

16. Kartashova O.N. Zimostojkost' i produktivnost' novyh sortov vishni v usloviyah Nechernozem'ya: avtoref. dis. ... kand. c.-h. nauk : 06.01.05 / Kartashova Ol'ga Nikolaevna. Moskva, 2009. $26 \mathrm{~s}$. 
17. Lenivceva M.S., Orekhova V.P., Lukicheva L.A. Ustojchivost' sortov chereshni i vishni k kokkomikozu (Coccomyces hiemalis Higg.) // Katalog mirovoj kollekcii VIR. 2010. №799. $18 \mathrm{~s}$.

18. Wharton P.S., Iezzoni A., Jones A.L. Screening cherry germ plasm for resistance to leaf spot // Plant Disease. 2003. V. 87(5). P. 471-477.

19. Wharton P.S., Iezzoni A. Development of a protocol for screening cherry germplasm for resistance to cherry leaf spot // Acta Horticulturae. 2005. V. 667. R. 509-514.

20. Lenivceva M.S., Radchenko E.E., Kuznecova A.P. Geneticheskoe raznoobrazie sortov kostochkovyh kul'tur (rod Rrunus L.), ustojchivyh k kokkomikozu // Sel'skohozyajstvennaya biologiya. 2017. T. 52. № 5. S. 895-904.

21. Kuznecova A.P. Specializaciya i vnutrividovaya differenciaciya vozbuditelya kokkomikoza // Optimizaciya fitosanitarnogo sostoyaniya sadov v usloviyah pogodnyh stressov. Krasnodar, 2005. S. 82-88.

22. Lenivceva M.S., Kuznecova A.P., Radchenko E.E. Vnutrividovaya izmenchivost' Soccomyces hiemalis po priznaku virulentnosti k obrazcam chereshni i vishni // Mikologiya i fitopatologiya. 2016. T. 50. № 1. S. 62-65.

23. Lenivceva M.S., Kuznecova A.P. Rasovyj sostav populyacij vozbuditelya kokkomikoza Vlumeriella jaapii(rehm) v. Arx // Trudy po prikladnoj botanike, genetike i selekcii. 2011. T. 168. S. 162-164.

24. Lenivceva M.S., Kuznecova A.P. Fenotipicheskoe raznoobrazie trekh agroklimaticheskih zon Krasnodarskoj populyacii Soccomyces hiemalis po virulentnosti k obrazcam chereshni i vishni // Nauka Kubani. 2018. №3. S.44-47.

25. Ul'yanovskaya E.V., Artyuh S.N., Efimova I.L., Mozhar N.V. [i dr.] Sohranit' i vsestoronne izuchit' geneticheskie resursy plodovyh i ih podvoev, yagodnyh, orekhoplodnyh, cvetochno-dekorativnyh kul'tur i vinograda s cel'yu vydeleniya i sozdaniya donorov i istochnikov hozyajstvenno znachimyh priznakov novyh sortov dlya obespecheniya effektivnosti i ekologizacii selekcii, sadovodstva i vinogradarstva: otchet o NIR (Severo-Kavkazskij zonal'nyj nauchno-issledovatel'skij institut sadovodstva i vinogradarstva RASHN) 2013. 786 s. № GR: 01201265696 .

26. Kruzhkov A.V. Podbor roditel'skih form v selekcii vishni na ustojchivost' k kokkomikozu // Vavilovskie chteniya: materialy mezhdunar. nauch-prakt. konf. Saratov, 2011. S. 40-41.

27. Lenivceva M.S., Kuznecova A.P. Tipy i istochniki ustojchivosti kostochkovyh kul'tur k kokkomikozu // Vestnik APK Stavropol'ya. 2016. № 4 (24). S. 179-182.

28. Lenivceva M.S. Izuchenie ustojchivosti kostochkovyh kul'tur k kokkomikozu: metodicheskie ukazaniya. SPb.: VIR, 2010. 28 s.

29. Metodika opytnogo dela i metodicheskie rekomendacii Severo-Kavkazskogo zonal'nogo NII sadovodstva i vinogradarstva. Krasnodar, 2002. 215 s.

30. Programma selekcionnyh rabot po plodovym, yagodnym, orehoplodnym i cvetochno-dekorativnym kul'turam soyuza selekcionerov Severnogo Kavkaza na period do 2010 g. Krasnodar, 2005. 343 s. 